\title{
Reconstruction of the Sakinah Family Criteria During the Covid-19 Period
}

\author{
Andi Yaqub ${ }^{1}$, Iswandi ${ }^{2}$, Jabal Nur ${ }^{3}$ \\ ${ }^{1}$ Institut Agama Islam Negeri (IAIN) Kendari - Indonesia, ${ }^{2}$ Pelangi Majang \\ Institute (PMI) Bone - Indonesia, ${ }^{3}$ Institut Agama Islam Negeri (IAIN) Kendari - \\ Indonesia \\ 1andiyaqub@iainkendari.ac.id, 2Iswandish239@gmail.com, \\ 3Sibalisibali97@gmail.com
}

\begin{abstract}
This article describes the implementation and achievements of the sakinah family during the Covid-19 period. Both refer to the technical guidelines of the Indonesian Ministry of Religious Affairs in 2011 regarding the criteria for the sakinah family. This study uses sociological and al-mașlahah approaches. The research location is in Konda District, Konawe Selatan Regency. The researchers obtained data from the Office of Religious Affairs (KUA), sub-district government, village heads, community leaders, and the public. This study found that the criteria for the sakinah family were irrelevant to apply. The reason is that the expectations of these criteria are too high, especially in the fields of economy and social status. In addition, the KUA officers did not implement the sakinah family counseling properly. Thus, the criteria for the sakinah family need to be simplified and adapted to the conditions and characteristics of each region.
\end{abstract}

Keyword: sakinah family; financial; social; religious; transformation

[]

Tulisan ini mendeskripsikan implementasi dan pencapaian keluarga sakinah di masa Covid-19. Keduanya mengacu kepada petunjuk teknis Kementerian Agama Republik Indonesia tahun 2011 tentang kriteria keluarga sakinah. Penelitian ini menggunakan pendekatan sosiologi dan al-mașlahah. Lokasi penelitian berada di Kecamatan Konda, Kabupaten Konawe Selatan. Peneliti memperoleh data dari pihak Kantor Urusan Agama (KUA), pemerintah kecamatan, kepala desa, tokoh masyarakat, dan masyarakat umum. Penelitian ini menemukan bahwa kriteria keluarga sakinnah tersebut tidak relevan untuk diterapkan. Penyebabnya yaitu ekspektasi kriteria tersebut terlalu tinggi, khususnya dalam bidang ekonomi dan status sosial. Selain itu, pihak KUA tidak mengimplementasikan penyuluhan keluarga sakinah dengan baik. Dengan demikian, kriteria keluarga sakinnah perlu disederhanakan dan disesuaikan dengan kondisi dan karakter masing-masing wilayah.

Kata Kunci: keluarga sakinah; finansial; sosial; keagamaan; transformasi 
Andi Ya'qub, Iswandi, Jabal Nur

\section{Introduction}

The community experienced several obstacles in realizing the sakinah family. ${ }^{1}$ These constraints refer to the criteria for the sakinah family published by the Ministry of Religion in 2011.2 Primarily on the economic and social strata aspects in addition to religious values. This criterion contradicts the reality in society. Especially at this time, the Covid-19 pandemic also affected the incompatibility of these criteria. Covid-19 may impact psychological, economic and social aspects. This fact has an impact on the difficulties of the community in realizing the sakinah family. In addition, it also made it difficult for Office of Religious Affairs (KUA) officers to provide information to the community. ${ }^{3}$ On the other hand, Kuswanti stated that Covid-19 could reduce family conflicts. The trick is to increase the effectiveness of communication, organization, and responsible entities. ${ }^{4}$

The criteria for the sakinah family in the formulation of the Ministry of Religion make the financial aspects and social strata as benchmarks. Meanwhile, the reality in society shows that they have implemented the values and essence of the sakinah family. The concrete form is seen in their activeness in social activities, both religious and social. With this activity, communication patterns between communities are harmonious, regardless of the economic conditions of each citizen. They can make a comfortable and happy life, even during the Covid-19 pandemic.

1 Danu Aris Setiyanto, 'Konstruksi Pembangunan Hukum Keluarga di Indonesia Melalui Pendekatan Psikologi', Al-Ahkam 27, no. 1 (9 June 2017): 26, https://doi.org/10.21580/ahkam.2017.27.1.1183.

2 Yunika Isma Setyaningsih and Malik Ibrahim, 'Keluarga Berencana dalam Rangka Mewujudkan Keluarga Sakinah di Mungkid, Magelang, Jawa Tengah', AlAhwal: Jurnal Hukum Keluarga Islam 5, no. 2 (26 September 2012): 111-40, http://ejournal.uin-suka.ac.id/syariah/Ahwal/article/view/1122.

3 Marmiati Mawardi, 'Keluarga Sakinah: Konsep \& Pola Pembinaan', International Journal Ihya' 'Ulum Al-Din 18, no. 2 (7 September 2016): 253, https://doi.org/10.21580/ihya.17.2.1739.

${ }^{4}$ Ana Kuswanti et al., 'Manajemen Komunikasi Keluarga Saat Pandemi COVID19', SALAM: Jurnal Sosial dan Budaya Syar-I 7, no. 8 (19 July 2020): 16, https:// doi.org/10.15408/sjsbs.v7i8.15959; I Gusti Ngurah Santika, 'Optimalisasi Peran Keluarga dalam Menghadapi Persoalan Covid-19: Sebuah Kajian Literatur', Jurnal Ilmiah Ilmu Sosial 6, no. 2 (18 December 2020): 127-37, https://doi.org /10.23887/jiis.v6i2.28437. 
Creating a sakinah family, in any condition, is a basic need. It is needed to attain happiness by fulfilling mașālih usrah and mașālih āmmah. ${ }^{5}$ One crucial aspect is family financial management during a pandemic. Every family needs to manage it well to get through the crisis with calm. ${ }^{6}$ Another aspect is psychological, which puts pressure on family life. The Covid-19 pandemic significantly limits activities and changes habits that can lead to anxiety and depression. ${ }^{7}$ Therefore, it is essential to study the sakinah family during a pandemic.

This research focuses on implementing and achieving the sakinah family in Konda District, Konawe Regency, during the Covid-19 pandemic. Both refer to the criteria for the sakinah family formulated by the Ministry of Religion in 2011. The main questions in this paper are, first, what caused the failure to realize the sakinah family in Konda District, Konawe Regency, during the Covid-19 period? Second, how did the people of Konda District, Konawe Selatan Regency during Covid-19, realize the sakinah family?

This research is field research with a descriptive-qualitative method. We observe the criteria for the sakinah family in 2011 and the facts in the community during the Covid-19 period. We obtained the data by interview from KUA officers in Konda District, Village Heads, Community Leaders, and the

${ }^{5}$ Mujiburrahman, 'Konsep Keluarga Mașlahah Menurut Pengurus Lembaga Kemaslahatan Keluarga Nahdlatul Ulama (LKK NU) Daerah Istimewa Yogyakarta (DIY)', Al-Ahwal Jurnal Hukum Keluarga Islam 10, no. 2 (7 January 2017): 14855, http://ejournal.uin-suka.ac.id/syariah/Ahwal/article/view/1309/1316; Yasin Yusuf Abdillah, 'Perjanjian Perkawinan Sebagai Upaya Membentuk Keluarga Bahagia (Tinjauan Maqāșid Asy-Syarī'Ah)', Al-Ahwal: Jurnal Hukum Keluarga Islam 10, no. 2 (7 January 2017), https://doi.org/10.14421/ahwal. 2017.10205.

${ }^{6}$ Agusdiwana Suarni and Arman Rahim Sawal, 'Peran Akuntansi dalam Rumah Tangga dan Penerapan Pengelolaan Keuangan Rumah Tangga Secara Islami di Masa Pandemi Covid-19', Assets: Jurnal Ekonomi, Manajemen dan Akuntansi 10, no. 2 (2020): 110-29, https://doi.org/10.24252/ASSETS.V10I2. 18594; Muhammad Ramli and Mulono Apriyanto, 'Manajemen Keuangan Untuk Meningkatkan Perekonomian Keluarga di Masa Pandemi Covid-19', Selodang Mayang: Jurnal Ilmiah Badan Perencanaan Pembangunan Daerah Kabupaten Indragiri Hilir 6, no. 3 (16 December 2020): 1-8, https://ojs.selodangmayang. com/index.php/bappeda/article/view/188.

7Jarnawi Jarnawi, 'Mengelola Cemas di Tengah Pandemik Corona", At-Taujih : Bimbingan dan Konseling Islam 3, no. 1 (30 June 2020), https://doi.org/10. 22373/taujih.v3i1.7216. 
General Public. This research uses a sociological and welfare approach. The following pattern analyzed the collected data. First, data reduction, second, the presentation of the structure, third, concluding.

\section{The Sakinah Family in the 2011 Indonesian Ministry of Religion Framing}

The Indonesian Ministry of Religious Affairs framing the criteria for the sakinah family is considered a universal discriminatory action against community groups. The formulation of these criteria suggests that family happiness and peace will only be reached if they get a proper position in the social environment. Both ideologically and targeted, these criteria do not have a precise orientation. It even gives the impression of a pragmatic, materialistic, capitalistic element. Creating a sakinah family for a family becomes a kind of worldly competition. The sakinah family, which should have been oriented towards divinity and humanity were neglected.

The stages of the sakinah family I, II, III, and III Plus ${ }^{8}$ explain that everything can be obtained when a family has a particular financial position. These criteria and stages are far from the principal value of marriage. The following is an explanation of the steps and measures formulated by the Ministry of Religion in 2011.

\section{a. Financial Framing as a Benchmark}

The criteria for the sakinah family in 2011 show that to create a happy family; the financial side must be fulfilled. Defining happiness only from a financial standpoint is a mistake. If applied universally, this error is related to the level of need which is also divided into two parts, physical and spiritual. The material cannot be used to measure the level of happiness. The criteria set by the Ministry of Religion, particularly in terms of finance, are as follows.

8 Direktorat Jenderal Bimbingan Masyarakat Islam dan Direktorat Urusan Agama Islam dan Pembinaan Syariah, Petunjuk Pelaksanaan Pemilihan Keluarga Sakinah Teladan, Kementerian Agama RI (Jakarta: Kementerian Agama RI Direktorat Jenderal Bimbingan Masyarakat Islam dan Direktorat Urusan Agama Islam dan Pembinaan Syariah, 2011). 
Table 1. The Financial Side

\begin{tabular}{|l|l|}
\hline \multicolumn{1}{|c|}{$\begin{array}{c}\text { Stages of the } \\
\text { Sakinah Family }\end{array}$} & \multicolumn{1}{c|}{ Criteria and/or Indicators of the Sakinah Family } \\
\hline Sakinah I & Fulfillment of basic daily needs \\
\hline Sakinah II & $\begin{array}{l}\text { 1. Have an income that exceeds the basic needs } \\
\text { 2. Minimum education level of Junior High School } \\
\text { 3. Owning your own house, even though it is simple } \\
\text { 4. Able to meet standard life, healthy food }\end{array}$ \\
\hline Sakinah III & $\begin{array}{l}\text { 1. Minimum high school level } \\
\text { 2. Able to perform qurban worship } \\
\text { 3. Able to carry out the pilgrimage }\end{array}$ \\
\hline Sakinah III Plus & $\begin{array}{l}\text { 1. Fulfills the provisions of the hajj mabrūr } \\
\text { 2. Able to increase infāq, sadaqah, jāriyah, and waqf, both } \\
\text { qualitatively and quantitatively }\end{array}$ \\
3. Have a minimum bachelor's diploma
\end{tabular}

Source; 2011 Ministry of Religious Affairs' Sakinah Family Guidance Technical Guidelines

Based on these four components, it appears that the economic aspect is the point of emphasis. Stage I is still considered rational because it is the primary need of a family. However, stages II, III, and III plus are further provisions that come out of the essence of happiness. Realizing the four stages is the community's responsibility and involves KUA officers. They are in charge of providing guidance and counseling. Jalil stated that the economic side of the family is not about competing in seeking the maximum income, but rather the family financial managerial system. The way a family controls the economy is not to be wasteful and uses it as needed. ${ }^{9}$

Family financial orientation will be good when directed to managing finances well-not formulating achievement criteria that encourage society to be pragmatic. Islam has regulated the use of finance tailored to the needs and can handle it properly. ${ }^{10}$ This general rule contradicts the criteria for the sakinah family formulated by the Ministry of Religion in 2011.

${ }^{9}$ Abdul Jalil, 'Pengelolaan Keuangan Keluarga Solusi Keluarga Sakinah', Al Maqashidi 2, no. 1 (2 August 2019): 18, http://ejournal.sunan-giri.ac.id/index. php/ALMAQASHIDI/article/view/188.

10 'Perempuan dan Uang Keluarga - Bimbingan Perkawinan', accessed 8 January 2021, http://bimbinganperkawinan.com/perempuan-dan-uang-keluarga/. 
These criteria will always be polemic. It will only encourage families who have the capacity and finances to get the title of family sakinah. The ability and economy trigger a pragmatic mindset, especially to be a winner in the race for the sakinah family against other families. The exemplary sakinah family is a competition design so that people are required to compete and chase in achieving the perfection of family life. In addition, there are contradictions between stages. Only families with an excellent economic level can participate in the event.

\section{b. Social Strata as an Inhibiting Factor}

Occupying a specific position in society is one indicator of the sakinah family. It is an essential instrument by the 2011 technical guidelines as follows.

Table 2. Social Strata

\begin{tabular}{|l|l|}
\hline \multicolumn{1}{|c|}{$\begin{array}{c}\text { Stages of the } \\
\text { Sakinah Family }\end{array}$} & \multicolumn{1}{|c|}{ Criteria and/or Indicators of the Sakinah Family } \\
\hline Sakinah II & Active in socio-religious activities \\
\hline Sakinnah III & $\begin{array}{l}\text { Being active in the management of religious and social } \\
\text { activities }\end{array}$ \\
\hline Sakinah III Plus & $\begin{array}{l}\text { 1. Become a religious, community and organizational figure } \\
\text { 2. Increase the interest of the family and society in fulfilling } \\
\text { religious teachings. }\end{array}$ \\
\hline
\end{tabular}

Source; 2011 Ministry of Religious Affairs' Sakinah Family Guidance Technical Guidelines

The social aspect - being involved in social activities - is stated in the sakinah family II, III, III Plus criteria. The parameters for this social stratum are found in the activeness of the family in all activities, both social and religious, being the management of organizations, religious leaders, and adjusting the Hajj correctly and adequately and the Hajj mabrur. Some of these indicators show that the sakinah family can be achieved when each family is active in social activities, mainly occupying certain positions in the various activities. The sakinah family can only be obtained by those who influence society. This provision indicates an element of discrimination and creates competition. The sakinah family criteria in 2011 are an anomaly and a failure to understand the reality of society as a whole. Measuring family happiness only from occupying certain social strata has a harmful impact. 
The results of observations and interviews with respondents regarding creating a happy family received various answers. Each family answers according to their respective ways of maintaining and realizing household happiness. From this, it appears that there are problems in the criteria for the sakinah family:

1. The community does not understand the requirements of the sakinah family well.

2. Different answers indicate a lack of standard flow. Society is more based on the criteria of a happy family on personal experiences and messages from family ancestors.

3. The expectations of the sakinah family's criteria are too high. The social position, guidance, mentoring, and counseling that is not optimal also contribute to the failure to achieve the indicators of the sakinah family.

More than that, the data collection on the sakinah family conducted by the Ministry of Religion is not based on real cases in the community. This lack of clarity has resulted in the measurement and conclusion of the data being abstract. It is necessary to re-record the sakinah family based on fair standards and measurements. Re-registering the existence of the Sakinah family is crucial evidence to compare and measure the extent of the influence of the previously agreed criteria for the sakinah family. Thus, the progress of achieving the Sakinah family and the role of the KUA is the primary keys for collecting data by the stages of achievement, especially when it is related to the current pandemic condition.

\section{c. Sakinah Family; A Competition Design}

Being a sakinah family is a means of competition in the search for exemplary families in the packaging of the Ministry of Religion. Being a sakinah family in this scheme is only used as a competitive arena. It is no longer a form to realize essential happiness as a whole. For example, the winner of the 2016 exemplary family is required to be mature in terms of economy, understanding of religion, fostering and educating children, and involvement in community social organizations. ${ }^{11}$ At the same time, people are required to live in harmony and

11 'Mengungkap Rahasia Pemenang Keluarga Sakinah Teladan Nasional | Suara Muhammadiyah', accessed 9 January 2021, https://suaramuhammadiyah. 
side by side to create a sense of care among fellow human beings. From this condition, it can be understood that the sakinah family is not a competition but a noble achievement. Two things are counterproductive; on the one hand, there is a demand to live in harmony and peace. On the other hand, there is a demand to compete.

Before being officially registered as a contestant of the sakinah family competitions, they must fulfill some conditions. Families as participants in the sakinah family competition must satisfy the following aspects. They are first related to the understanding and practice of Islamic teachings, second, corresponding to the appreciation and experience of national life. Third, marriage, domestic life, and fourth are related to general knowledge.12 Emphasis is on the technical guidelines for the position of the sakinah family, and the criteria for a married couple as participants as the competitive technical guidelines are on the maturity side.

\section{Community Dynamics in Konda District, Konawe Selatan Regency}

The sakinah family in society fluctuates when faced with the criteria for the sakinah family. The head of KUA Konda stated that his party experienced problems in realizing the sakinah family if they followed the requirements from the Ministry of Religion. The obstacles are very high expectations, the maturity of one family's religious understanding, and the maturity of the economy income - parents, and children. ${ }^{13}$ The criterion contradicts the reality of the people in the Konda District. They depend more on agriculture and small businesses. That is, they are accustomed to living. ${ }^{4}$

id/2016/08/26/mengungkap-rahasia-pemenang-keluarga-sakinah-teladannasional/.

12 Direktorat Jenderal Bimbingan Masyarakat Islam dan Direktorat Urusan Agama Islam dan Pembinaan Syariah, Petunjuk Pelaksanaan Pemilihan Keluarga Sakinah Teladan, Kementerian Agama RI, 9-12.

${ }^{13}$ Rusdan Head of Coordination for Religious Affairs, Konda District, South Konawe Regency "Interview" at the Office on October 29, 2020.

${ }^{14}$ Bahtiar, BA, Secretary of the District Head of Konda District, South Konawe District, Seektronik "Interview" at Kontor on November 2, 2020. 
Meanwhile, village heads and religious leaders in Konda District stated that community and family harmony looks positive. In detail, some of the responses are presented in the following table.

Table 3. The Response of the Village Government and Community Leaders

\begin{tabular}{|c|c|c|}
\hline 1. & $\begin{array}{l}\text { Jafar as Village } \\
\text { Head and Imam of } \\
\text { Pombulaa Jaya } \\
\text { Village }\end{array}$ & $\begin{array}{l}\text { "The harmony of the community, including in this village, } \\
\text { is well established. It is very rare to find domestic conflicts. } \\
\text { Meanwhile, when a household conflict occurs, it can still } \\
\text { be resolved. The village government is directly involved to } \\
\text { carry out mediation with both parties before household } \\
\text { problems reach the stage of divorce" }\end{array}$ \\
\hline 2. & $\begin{array}{l}\text { Leory as Village } \\
\text { Head and Village } \\
\text { Imam (Lebo Jaya) }\end{array}$ & $\begin{array}{l}\text { "The sakinah family in this village was achieved } \\
\text { positively. The community sometimes asks for opinions } \\
\text { from the government in case of domestic conflicts. On the } \\
\text { other hand, household and community harmony is well } \\
\text { maintained". }\end{array}$ \\
\hline 3. & Lombusa Village & $\begin{array}{l}\text { "Usually, before or after marriage, we take the time to } \\
\text { talk about the position of the family and how to build their } \\
\text { family's future later." }\end{array}$ \\
\hline 4. & Konda 1 Village & $\begin{array}{l}\text { "In realizing the sakinah family, the judiciary and civil } \\
\text { registration have collaborated to socialize Law no. } 16 \text { of } \\
2019 \text { concerning Marriage. In general, family life in this } \\
\text { village is still going well " }\end{array}$ \\
\hline 5. & $\begin{array}{l}\text { Suyanto as Village } \\
\text { Head of Wanua }\end{array}$ & $\begin{array}{l}\text { "Family life in Wanua village is harmonious. Here, } \\
\text { communication between people is open" }\end{array}$ \\
\hline 6. & $\begin{array}{l}\text { Kuswara as Village } \\
\text { head of Lowaila }\end{array}$ & $\begin{array}{l}\text { "The community here is well preserved. Family conflicts } \\
\text { rarely occur" }\end{array}$ \\
\hline 7. & $\begin{array}{l}\text { Banjirun as Imam } \\
\text { of Masagena } \\
\text { Village }\end{array}$ & $\begin{array}{l}\text { "Family conditions in this village are good and domestic } \\
\text { conflicts are very rare. Community participation in } \\
\text { society and religion is classified as good even though not } \\
\text { all of them are involved" }\end{array}$ \\
\hline 8. & Konda Village & $\begin{array}{l}\text { "The family conditions here are still relatively } \\
\text { harmonious and conflicts rarely occur. At best, it's just } \\
\text { spat and not getting to the stage of divorce. The harmony } \\
\text { of the family and the community environment still looks } \\
\text { harmonious, respects each other" }\end{array}$ \\
\hline
\end{tabular}

\section{a. Family Economic Aspects in Realizing the Sakinah Family}

Realizing the sakinah family, according to Sakuariadi, cannot be measured from one point of view. Moreover, when parents spend more of their time making a living, they don't have enough time to create happiness. Creating 
harmonious family relationships requires a balance between this world and the hereafter..15 Creating a balance can be done, for example, by empowering community groups. They can teach children to recite the Koran or read and write the Koran. It aims to educate future generations through religious teaching. 16

The economic aspect of husband-wife and family life is not the main factor causing family conflicts. Based on interviews with several village heads, financial problems are the minor factor that affects household conflicts. It is because most people live and depend on the agricultural sector. His daily needs are fulfilled by farming products and sales. Likewise, in the conditions of the Covid-19 pandemic as it is today. Although it has a financial impact, it does not cause conflict.17

The following is a graph of the public's statement regarding the financial position of the sakinah family's achievements during the Covid-19 period.

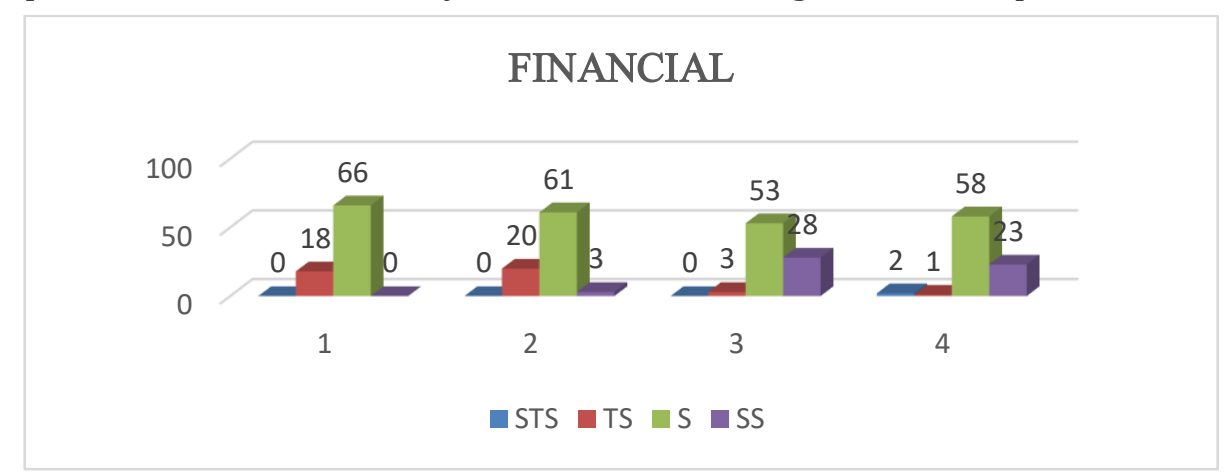

Figure 1. Public Statement on Finance

Based on 84 respondents regarding family conditions during the Covid-19 pandemic, 18 respondents (21\%) strongly agreed and had no significant impact and influence on financial pressure on household (family) life. Meanwhile, 66 respondents (79\%) stated that finance impacts households. Meanwhile,

\footnotetext{
${ }^{15}$ Sakuriadi, Community Leader of Pombulaa Jaya Village, interview at the residence on November 19, 2020.

${ }^{16}$ Jafar, Village Head of Pombulaa Jaya, interview at the residence of On Stairs; November 14, 2020

${ }^{17}$ Interview information from the statements of each village head, as for the village (location) for collecting the data, namely: Konda I, Pombulaa Jaya, Wanua, Lebo Jaya, Konda, Lamomea, Lowaila, Lambusa, and Masagena Villages.
} 
concerning economic relations and the sakinah family, as many as 20 respondents (24\%) said that finance is a significant cause of household failure. Meanwhile, 63 respondents (73\%) agreed, and one respondent strongly agreed (3\%) that finance is not the leading cause of loss of husband and wife and family in realizing a sakinah family. In addition, that achieving happiness is not only measured in financial terms. Thus, based on the statement, there are two respondents $(3 \%)$ who disagree, one respondent (1\%) strongly agrees, 58 respondents (69\%) agree, and 23 respondents (27\%) strongly agree.

\section{b. Social Aspects in Realizing the Sakinah Family}

Social and religious activities can be seen from the weekly recitation at the mosque. The recitation group is divided into two, housewives and heads of households. The particular recitation for homemakers is held on Wednesday afternoon, and for the head of the family is held on Thursday nights. ${ }^{18}$ Many religious activities are initiated by and with the awareness of the community. ${ }^{19}$ These activities have a positive impact, starting from the level of togetherness, social, to the level of application of the values of tolerance..$^{20}$ The tolerant value can be seen from their ability to live side by side without contradicting their respective faiths. It shows that the entity's awareness of social life has been implemented well.

Banjirun, as the Imam of Masagena Village, said that the living conditions of the family and the community were classified as positive. The same thing was expressed by Iman as the Imam of Lebo Jaya Village, Muh. Ilham as the Imam of Pombula Jaya Village, and Muh. Roy Sodin as the Imam of Wanua Village. As the Head of Wanua Village, Suyanto said that social values are well embedded so that the residents live in harmony. One example is when there is an activity; the community works together to help each other. Agusalim conveyed the same information as the Head of Konda I Village, Kuswara as Head of Lowaila Village, M. Chairul Rojikin as Head of Lambusa Village, Musriyadi as Head of Konda

18 Jafar Village Head of Pombulaa Jaya, interview was conducted at his residence, on November 14, 2020.

${ }^{19}$ Leory, Village Head of Lebo Jaya, interview at his residence on November 16, 2020.

${ }^{20}$ M. Choirul Rojikin, Village Head of Lambusa interview at his residence on November 12, 2020. 
Village, Sukri Hakim as Head of Lamomea Village, and Luran Rey as Head of Masagena Village.

The social context as an indicator of the achievement of the sakinah family is divided into two, namely social and religious societies. Social society is the involvement of families in social activities, such as cooperation and mutual assistance. Meanwhile, socio-religion is the involvement of the community in religious ritual activities. Regarding the two contexts, the following is the response from the district.

\section{1) Social Society}

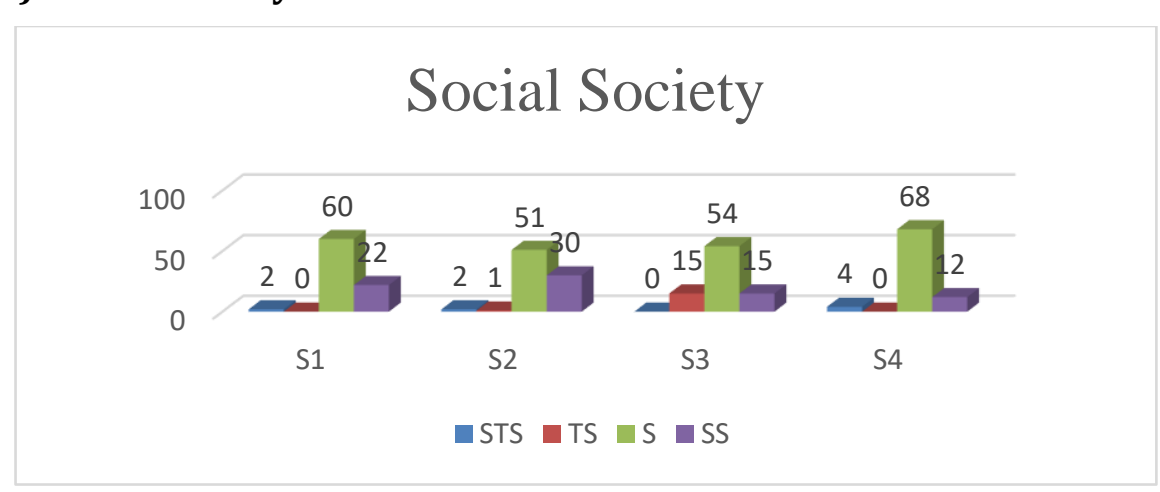

Figure 2. Social Society

Regarding activeness in community social activities, it positively impacts people's lives. In this case, as many as two respondents (2\%) strongly disagreed, 60 respondents $(72 \%)$ gave concurrent information, and 22 respondents strongly agreed. In addition, involvement in social activities has a positive impact on family life compared to not being involved; there are two respondents (2\%) who strongly disagree, one respondent (1\%) disagrees, 51 respondents (61\%) agree, and 30 respondents (36\%) strongly agree. Meanwhile, related communication and financial patterns do not have a negative impact, everything can normally run when helping each other, and family communication is more improved and responsive. There are $0 \%$ who strongly disagree, 15 respondents (18\%) disagree, 54 respondents (64\%) agree, and 15 respondents (18\%) strongly agree. Related to increasing social awareness, reducing the level of domestic violence. A total of 4 respondents (5\%) strongly disagree, $0 \%$ disagree, 68 respondents (81\%) agree, 12 respondents (14\%) strongly agree. 


\section{2) Religious Social}

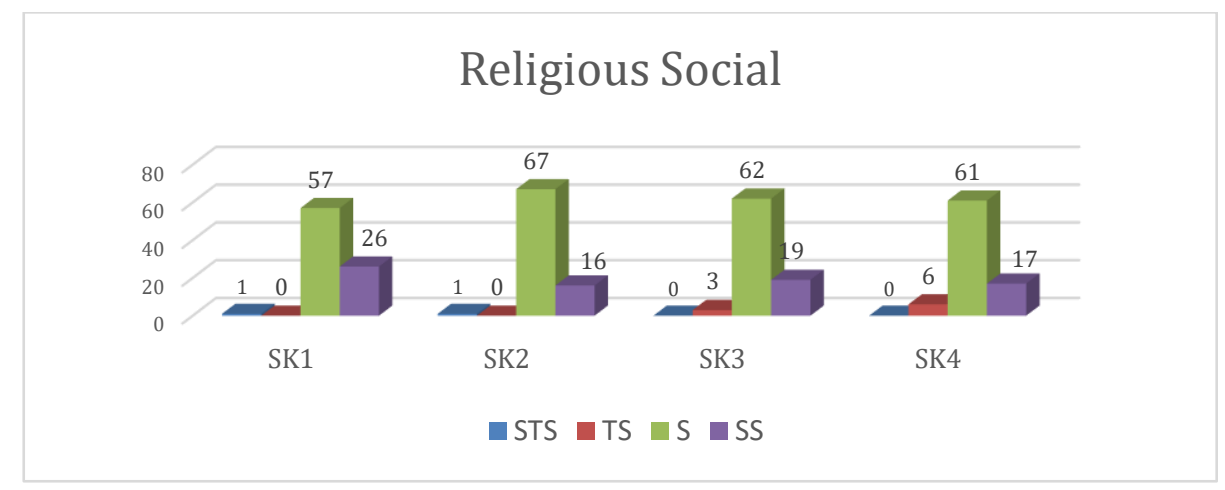

Figure 3. Religious Social

Social religion is an important factor in family life. Family participation in religious activities can increase understanding of religion and positively impact family life. In this regard, 1 respondent (3\%) strongly disagrees, $0 \%$ disagrees, 37 respondents (74\%) agree, and 26 respondents (23\%) strongly agree. Regarding involvement, it is not a financial issue and does not have a negative impact; there is one respondent (1\%) who strongly disagrees, $0 \%$ disagree, 67 respondents (80\%) agree, and 16 respondents (19\%) strongly agree. In the aspect of socio-religious activities, it has benefits to society in the form of increased communication with family and society, $0 \%$ answered strongly disagree, three respondents (3\%) disagree, 62 respondents (74\%) agree, 19 respondents $(23 \%)$ stated strongly agree. Family involvement in recitation activities has a positive impact in minimizing household conflicts compared to not being involved; as many as $0 \%$ answered strongly disagree, six respondents (7\%) disagreed, 61 respondents (73\%) agreed, and 16 respondents (20\%) ) strongly agree.

\section{c. Coaching and Counseling; The Main Problem in Realizing the Sakinah Family}

In creating the sakinah family, Mislan stated that one must include the community for them to know about the sakinah family in conducting counseling. ${ }^{21}$ However, under the conditions of Covid-19, activities were

21 Mislan Extension of KUA, Konda District, South Konawe Regency "interview" KUA Place, on November 20, 2020. 
hampered. The use of technology as an extension instrument cannot be used optimally due to the limited state of society. The extension process in Konda 1 Village was carried out in collaboration with the court and the district head but did not involve community participation.22 Unlike in Wanua Village, the guidance and counseling of the sakinah family involve the local community, and IAIN Kendari carries it out by limiting the number of participation..$^{23}$ The ineffectiveness of the sakinah family counseling is an inhibiting factor in realizing the sakinah family. ${ }^{24}$

According to Mawardi, guidance and counseling activities for the sakinah family did not go as expected. One of the problems is that KUA officers providing advice and assistance are not based on the criteria of the sakinah family. The KUA officers conducted this kind of attitude because there were several obstacles: not being programmed, conditional, and without planning. ${ }^{25}$ These three factors cause the failure of the Sakinah family and the realization of the criteria for the Sakinah family amid society.

\section{Transformation of the Sakinnah Family}

The transformation of the criteria for the sakinah family is based on several factors:

1. Covid-19. As a result of the disaster, the community failed to develop their household towards the sakinah family.

2. The criteria of the Ministry of Religion do not generally accommodate families. Only those who have middle-to-upper income and have a social position can reach the rank of the sakinah family.

3. The involvement of KUA extension agents is not effective by their duties and responsibilities.

The reconstruction of the criteria for the sakinah family is thus essential to answer the realities on the ground.

${ }^{22}$ Agusalim Village Head of Konda I, interview at home, on November 17, 2020.

${ }^{23}$ Suyanto, Village Head of Wanua, interview at home, on November 14, 2020.

${ }^{24}$ Suilstiyowati, Ernawati, Ali Mahfuddin, and Mislan, KUA Extension in Konda District, South Konawe Regency, interview at the KUA Office, on November 20, 2020.

25 Mawardi, 'Keluarga Sakinah: Konsep \& Pola Pembinaan', 259. 
In reality, community social activities positively impact society in general. For example, the recitation activity carried out by the community of one integrated sub-district from all villages initiated by a pesantren-based educational institution and in collaboration with the government has had a positive impact. This activity aims to build a religious and social understanding of the community to minimize family conflicts. In addition, it is also to provide knowledge to individuals and community groups. According to Asmaya, the implementation of the sakinah family in community life must be based on understanding and actions, both by the community and related institutions. ${ }^{26}$

The failure to realize two essential factors influence the sakinah family. First, the criteria of the Ministry of Religion in 2011 set a standard that was too high. Second, the participation of the KUA is not going well, even though it is central in guiding guidance regarding the existence and importance of the position of the sakinah family in household life. Therefore, several reasons for the need for the transformation of the sakinah family include:

\section{a. Discrimination in the Sakinah Family Criteria}

The criteria for the sakinah family in 2011 cannot represent the majority of married couples. Especially when looking at the financial aspects and social strata that the family has in the community. The financial factor, which is designed to consist of Sakinah I to III Plus, actually puts pressure on the family. Economic position and social strata only design individuals or small families. Apart from that, this position is a demand that must be achieved. So that it is not only the community (family) who feel heavy but including the KUA. They must implement and ensure that the family has applied the sakinah family criteria in their lives. The requirements for the sakinah family project in 2011 are;27

1) The standards elements are measured on a financial basis. It is estimated over basic needs, one of which is consuming healthy foods

2) Minimum education is set from high school to bachelor's degree.

3) Expenditures of infäq, șadaqah, and waqf are factors in realizing the sakinah family.

26 Enung Asmaya, 'Implementasi Agama dalam Mewujudkan Keluarga Sakinah', KOMUNIKA: Jurnal Dakwah dan Komunikasi 6, no. 1 (1 January 2012): 11, https://doi.org/10.24090/komunika.v6i1.341.

${ }^{27}$ Direktorat Jenderal Bimbingan Masyarakat Islam dan Direktorat Urusan Agama Islam dan Pembinaan Syariah, Petunjuk Pelaksanaan Pemilihan Keluarga Sakinah Teladan, Kementerian Agama RI, 10. 
4) Active as a manager and leader in the organization and community and religious leaders.

5) Perform hajj well and even become hajj mabrūr.

6) The minimum age limit of 30 years of marriage is categorized as part of the competency list of exemplary sakinah families.

\section{b. Mapping of Community Culture in Realizing Sakinah Family}

Based on the criteria for the sakinah family, to measure the sakinah family, the assessment criteria are given to the local KUA. ${ }^{28}$ They are given the authority to make criteria according to the regional context. Geographical location affects the character of society. Build a sakinah family based on a territorial context and free from the pressure of specific regulations from the center. KUA can make a pattern in realizing the sakinah family. They can make a strategy and determine an indicator of the criteria for the sakinah family. The goal is to recognize the sakinah family has its characteristics so that the requirements for the sakinah family for each region will vary according to the community culture and geographical conditions.

Besides the active and continuous guidance from the KUA, external support from each village is also needed to overcome several problems in achieving the sakinah family. ${ }^{29}$ The help and support from the sakinah family community may overcome those past failures, related realization, and implementation of counseling. Therefore, data entities and representations of the sakinah family can be measured in each region by building community and public awareness of the importance of the sakinah family. ${ }^{30}$ Conducting guidance and assistance

28 Erfaniah Zuhriah, 'Reformasi Gaya Berumah Tangga Melalui Model Keluarga Sakinah dalam Mencegah Perceraian', ADHKI: Journal of Islamic Family Law 1, no. 2 (2019): 100.

29 Samsidar Samsidar and Darliana Sormin, 'Program 'Aisyiyah dalam Mewujudkan Keluarga Sakinah Menuju Islam Berkemajuan', Intiqad: Jurnal Agama dan Pendidikan Islam 11, no. 1 (1 June 2019): 167, https://doi.org/10. 30596/intiqad.v11i1.3142.

30 Nispul Khairi, Ramadhan Syahmedi Siregar, and Julhaidir Purba, 'Efektivitas Bimbingan Perkawinan di Kantor Urusan Agama Kecamatan Sipispis Kabupaten Serdang Bedagai dalam Membangun Keluarga Sakinah dalam Perspektif Hukum Islam", At-Tafahum Journal of Islamic Law 3, no. 1 (7 January 2019): 28, http://jurnal.uinsu.ac.id/index.php/attafahum/article/view/6765. 
for the sakinah family can increase people's knowledge and understanding of the essential values of the sakinah family in the family. ${ }^{31}$

The Indonesian Ministry of Religious Affairs should revise the criteria of the sakinah family. Changes are made based on data and the legitimacy of Islamic law and marriage law. Both are used as a legal basis to fix the gaps in the 2011 sakinah family criteria. The improvement of the requirements is an obscenity to the family and society in general. It is necessary to simplify the requirements by adjusting the realities of the community, both from the cultural, social, customary, religious, characteristic, and geographic aspects of the local community.

Criteria can be used to build and realize the sakinah family has general characteristics. It is determined at the central level to be represented at the lower levels, the village, and urban levels. Meanwhile, at the sub-district level, it is the authority of the KUA. He has the authority to formulate the criteria for the sakinah family by the realities in society and the general provisions of the center. The centralized picture is as follows:

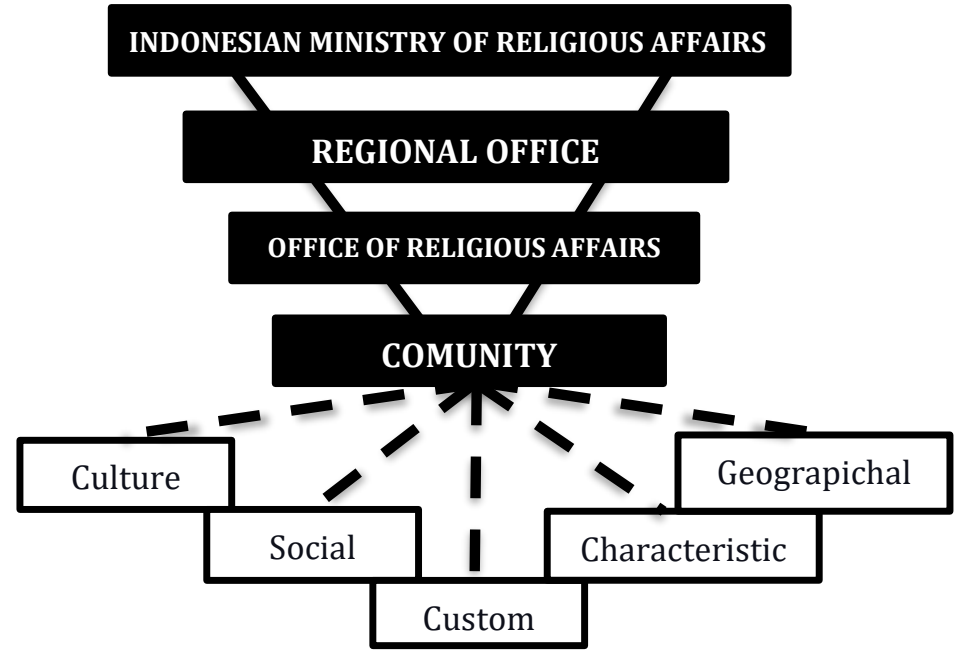

Figure 4. Centralization of Criteria for Sakinah Families

${ }^{31}$ Nidaul Millah, Wiryo Setiana, and Zaenal Muttaqin, 'Penyuluhan Agama untuk Meningkatkan Pemahaman Keluarga Sakinah', Irsyad: Jurnal Bimbingan, Penyuluhan, Konseling, dan Psikoterapi Islam 5, no. 1 (2017): 20, https://jurnal. fdk.uinsgd.ac.id/index.php/irsyad/article/view/887/172. 
The KUA has the authority and responsibility for realizing the sakinah family by formulating criteria in advance. KUA is central because they are more familiar with the community's terrain, conditions, and characteristics. To realize the sakinah family, the extension agent can determine the steps and strategies by reading and looking at these five variables. The goal is to make it easier to assist and foster the sakinah family. Knowing these five variables is a basic framework for creating indicators and criteria for the sakinah family. Apart from these five variables, Islamic law and marriage law are independent variables supporting and reinforcing a formulation of local standards.

\section{c. Changes in the Criteria for the Sakinah Family According to the Current Context}

The phenomenon of the criteria for the sakinah family in 2011 formulated by the Ministry of Religion versus cultural facts shows a need to make changes. In changing and reconstructing, the paradigm used refers to the formulation of maqāșid al-sharī'ah. ${ }^{32}$ The concept of maqāṣid al-sharī'ah is divided into several components, namely al-darūriyah (primary), al-hājjiyiah (secondary), and altahsiniyah (tertiary). ${ }^{33}$ These three components are used as an approach and thinking pattern. ${ }^{34}$ The maqāssid al-sharī'ah paradigm used in constructing the transformation of the criteria for the sakinah family occurs in the following table.

${ }^{32}$ Amin Farih, 'Reinterpretasi Mașlahah Sebagai Metode Istinbāt Hukum Islam: Studi Pemikiran Hukum Islam Abū İshāq Ibrāhīm Al-Shātịī', Al-Ahkam 25, no. 1 (25 April 2015): 24, https://doi.org/10.21580/ahkam.2015.1.25.193.

33 Jasser Auda, Maqāșid Al-Sharī'ah as Philosophy of Islamic Law A Systems Approach, I (London: The International Institute of Islamic Thought, 2007), 3, https://www.jasserauda.net/portal/wp-content/uploads/2016/11/Philoso phy_of_Islamic_Law-pdf-small.pdf; Supriyadi Widodo Eddyono, Perdagangan Manusia Dalam Rancangan KUHP (Jakarta: ELSAM in collaboration with The Asia Foundation and USAID, 2005); Ulfah Alfiyanti, Achmad Firdaus, and Dede Abdul Fatah, 'Hajj Financial Management in the Maqāșid Sharī'ah Perspective', AlAhkam 29, no. 2 (2019): 213-14, https://doi.org/http://dx.doi.org/10.21580/ ahkam.2019.29.2.3893; Syufa'at Syufa'at, 'Implementasi Maqāșid Al-Sharī'ah dalam Hukum Ekonomi Islam', Al-Ahkam 23, no. 2 (21 October 2013): 146-49, https://doi.org/10.21580/ahkam.2013.23.2.20.

34 M. Amin Abdullah, 'Epistemologi Keilmuan Kalam Dan Fikih Dalam Merespon Perubahan Di Era Negara-Bangsa Dan Globalisasi (Pemikiran Filsafat Keilmuan Agama Islam Jasser Auda)', Media Syari'ah: Wahana Kajian Hukum Islam Dan Pranata Sosial 14, no. 2 (30 October 2012): 140, https://doi.org/10. 22373/JMS.V14I2.1871. 
Table 4. Sakinah Family Reconstruction

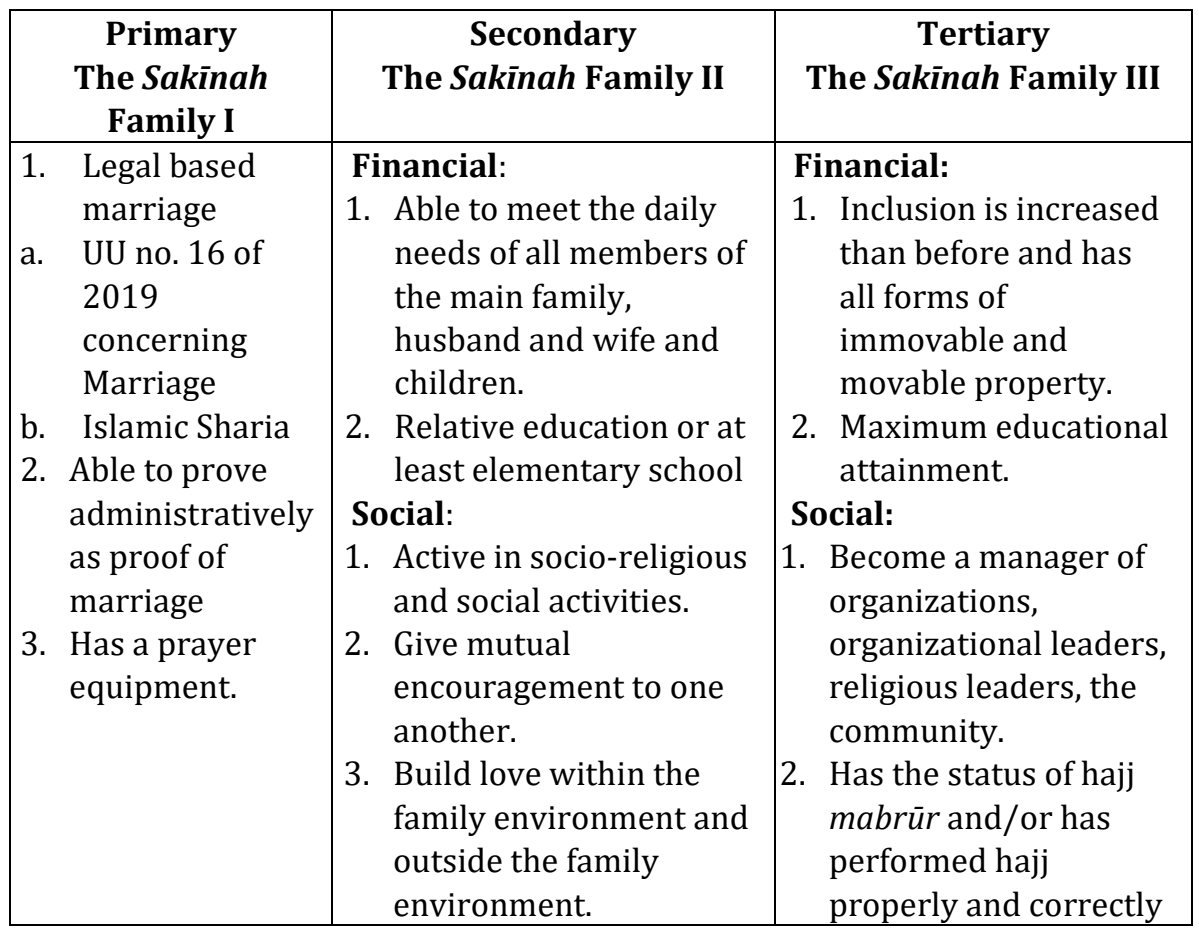

Creating a sakinah family means creating a happy household, world, and hereafter. ${ }^{35}$ Getting married has an absolute goal: creating a sakinah family in the home and family. Following maqasid al-sharīah, the sakinah aims to generate benefit in the family's life. Therefore, realizing the sakinah family is a darūrī determination, a necessity that must exist. He has the same position as marriage based on Islamic law and State law. The rest hājjiyah and tahsiniyah are complementary. Neither of them can transcend a point. If häjjiyah is not fulfilled, it will narrow space in life. For example, financial and social values are low. Meanwhile, tahsiniyyat is the achievement of the community (family) in

35 Risdawati Siregar, 'Urgensi Konseling Keluarga dalam Menciptkan Keluarga Sakinah", Himah II, no. 1 (2015): 88, http://repo.iain-padangsidim puan.ac.id/262/1/Risdawati Siregar.pdf. 
their household life, such as social, economic, and performing the hajj pilgrimage. 36

Renewal of these criteria has two fundamental values: social values and religious values. The Ministry of Religion formulated the sakinah family criteria as a general provision. They are then given to the KUA to explore according to the characteristics and geography of the area. Flexible application of the requirements leads to a dynamic assessment of the sakinah family. For example, in the conditions of Covid-19, society can still enforce the situation. The pandemic, although it did not have an impact on family happiness in Konda, it still had an impact. The real impact of a pandemic is on the economic and psychological side. The flexibility of the criteria for the sakinah family can still be applied. The transformation of the sakinah family within the community should not be grouped and hegemonized as a pragmatic society to create the sakinah family.

The reconstruction criteria for the sakinah family classifies the family into three parts, low, medium, and high. A family is included in the high category when it has fulfilled the three stages of the sakinah family I (primary), II (secondary), and III (tertiary). It means that a family already has a position and maturity from a spiritual and material perspective. Furthermore, the medium family occurs when the fulfillment of a family only reaches stages I (primary) and II (secondary). It means that the family has matured from the material side but has shortcomings on the social and spiritual side. Meanwhile, the low family is assigned to a family that meets the needs up to stage I (primary). The purpose of the three groupings is to make it easier for people to understand each community group that has achieved the achievements of the sakinah family. In the Covid-19 period, the groupings can realistically record family conditions to anticipate conflicts that occur.

\section{Conclusion}

The Covid-19 pandemic, with all its effects, does not have a strong enough impact on the realization of the sakinah family, especially the people in Konda District, South Konawe Regency. It does not affect the financial, social, and socioreligious sides. Two main factors influence the failure to realize the sakinah

${ }^{36}$ Moh Nasuka, 'Urgensi Maqasid Syari'ah dalam Membangun Keluarga Sakinah di Era Globalisasi', Isti'dal : Jurnal Studi Hukum Islam 3, no. 2 (2016): 111-19, https://ejournal.unisnu.ac.id/JSHI/article/view/685. 
family. First, the criteria for the sakinah family in the 2011 Ministry of Religion's technical guidelines are too high, especially for financial needs and social strata. Second, the KUA of Konda Subdistrict did not provide counseling. These two components are the main factors inhibiting the realization of the sakinah family in the Konda District. The Konda people state that financial need is not the main element in creating happiness. Meanwhile, active participation in socio-religious activities can provide positive energy. Failure to realize joy (family sakinah) is caused by many factors, mainly the two factors mentioned above.

As scientific research, this research only focuses on two variables, economic and social. Therefore, there are still many empty spaces that have not been touched, namely the problem of the average level of education, the effect of early marriage, and family communication in the manifestation of the sakinah family. Researchers provide recommendations for further research on these cases.[a]

\section{BIBLIOGRAPHY}

Abdillah, Yasin Yusuf. 'Perjanjian Perkawinan Sebagai Upaya Membentuk Keluarga Bahagia (Tinjauan Maqāșid AsySyarī'ah)'. Al-Ahwal: Jurnal Hukum Keluarga Islam 10, no. 2 (7 January 2017). https://doi.org/10.14421/ahwal.2017.10205.

Abdullah, M. Amin. 'Epistemologi Keilmuan Kalam dan Fikih dalam Merespon Perubahan di Era Negara-Bangsa dan Globalisasi (Pemikiran Filsafat Keilmuan Agama Islam Jasser Auda)'. Media Syari'ah: Wahana Kajian Hukum Islam Dan Pranata Sosial 14, no. 2 (30 October 2012): 123-50. https://doi.org/ 10.22373/JMS.V14I2.1871.

Alfiyanti, Ulfah, Achmad Firdaus, and Dede Abdul Fatah. 'Hajj Financial Management in the Maqāșid Sharī'ah Perspective'. Al-Ahkam 29, no. 2 (2019). https://doi.org/http://dx.doi.org/ 10.21580/ahkam.2019.29.2.3893.

Asmaya, Enung. 'Implementasi Agama dalam Mewujudkan Keluarga Sakinah'. KOMUNIKA: Jurnal Dakwah dan Komunikasi 6, no. 1 (1 January 2012). https://doi.org/10.24090/ komunika.v6i1.341.

Auda, Jasser. Maqāșid Al-Sharī'ah as Philosophy of Islamic Law A Systems Approach. I. London: The International Institute of Islamic Thought, 2007. https://www.jasserauda.net/portal/ 
wp-content/uploads/2016/11/Philosophy_of_Islamic_Lawpdf-small.pdf.

Direktorat Jenderal Bimbingan Masyarakat Islam dan Direktorat Urusan Agama Islam dan Pembinaan Syariah. Petunjuk Pelaksanaan Pemilihan Keluarga Sakinah Teladan, Kementerian Agama RI. Jakarta: Kementerian Agama RI Direktorat Jenderal Bimbingan Masyarakat Islam dan Direktorat Urusan Agama Islam dan Pembinaan Syariah, 2011.

Eddyono, Supriyadi Widodo. Perdagangan Manusia dalam Rancangan KUHP. Jakarta: ELSAM in collaboration with The Asia Foundation dan USAID, 2005.

Farih, Amin. 'Reinterpretasi Mașlahah Sebagai Metode Istinbāt Hukum Islam: Studi Pemikiran Hukum Islam Abū Ishāq Ibrāhīm Al-Shātibī'. Al-Ahkam 25, no. 1 (25 April 2015): 43. https://doi.org/10.21580/ahkam.2015.1.25.193.

Jalil, Abdul. 'Pengelolaan Keuangan Keluarga Solusi Keluarga Sakinah'. Al Maqashidi 2, no. 1 (2 August 2019): 67-84. http://ejournal.sunan-giri.ac.id/index.php/ALMAQASHIDI/ article/view/188.

Jarnawi, Jarnawi. 'Mengelola Cemas di Tengah Pandemik Corona". At-Taujih: Bimbingan dan Konseling Islam 3, no. 1 (30 June 2020). https://doi.org/10.22373/taujih.v3i1.7216.

Khairi, Nispul, Ramadhan Syahmedi Siregar, and Julhaidir Purba. 'Efektivitas Bimbingan Perkawinan di Kantor Urusan Agama Kecamatan Sipispis Kabupaten Serdang Bedagai dalam Membangun Keluarga Sakinah dalam Perspektif Hukum Islam". At-Tafahum Journal of Islamic Law 3, no. 1 (7 January 2019). http://jurnal.uinsu.ac.id/index.php/attafahum/article /view/6765.

Kuswanti, Ana, Munadhil Abdul Muqsith, Anna Gustina Zainal, and Selly Oktarina. 'Manajemen Komunikasi Keluarga Saat Pandemi COVID-19'. SALAM: Jurnal Sosial dan Budaya Syar-I 7, no. 8 (19 July 2020): 707-22. https://doi.org/10.15408/ sjsbs.v7i8.15959.

Mawardi, Marmiati. 'Keluarga Sakinah: Konsep \& Pola Pembinaan'. International Journal Ihya' 'Ulum Al-Din 18, no. 2 (7 September 2016): 253. https://doi.org/10.21580/ihya.17.2.1739.

'Mengungkap Rahasia Pemenang Keluarga Sakinah Teladan Nasional | Suara Muhammadiyah'. Accessed 9 January 2021. 
https://suaramuhammadiyah.id/2016/08/26/mengungkaprahasia-pemenang-keluarga-sakinah-teladan-nasional/.

Millah, Nidaul, Wiryo Setiana, and Zaenal Muttaqin. 'Penyuluhan Agama untuk Meningkatkan Pemahaman Keluarga Sakinah'. Irsyad: Jurnal Bimbingan, Penyuluhan, Konseling, dan Psikoterapi Islam 5, no. 1 (2017). https://jurnal.fdk.uinsgd. ac.id/index.php/irsyad/article/view/887/172.

Mujiburrahman. 'Konsep Keluarga Mașlahah Menurut Pengurus Lembaga Kemaslahatan Keluarga Nahdlatul Ulama (LKK NU) Daerah Istimewa Yogyakarta (DIY)'. Al-Ahwal Jurnal Hukum Keluarga Islam 10, no. 2 (7 January 2017): 148-55. http://ejournal.uin-suka.ac.id/syariah/Ahwal/article/view/ $1309 / 1316$.

Nasuka, Moh. 'Urgensi Maqasid Syari'ah dalam Membangun Keluarga Sakinah di Era Globalisasi'. Isti 'dal: Jurnal Studi Hukum Islam 3, no. 2 (2016): 111-19. https://ejournal.unisnu. ac.id/JSHI/article/view/685.

'Perempuan dan Uang Keluarga - Bimbingan Perkawinan'. Accessed 8 January 2021. http://bimbinganperkawinan.com/ perempuan-dan-uang-keluarga/.

Ramli, Muhammad, and Mulono Apriyanto. 'Manajemen Keuangan untuk Meningkatkan Perekonomian Keluarga di Masa Pandemi Covid-19'. Selodang Mayang: Jurnal Ilmiah Badan Perencanaan Pembangunan Daerah Kabupaten Indragiri Hilir 6, no. 3 (16 December 2020): 145-52. https://ojs.selodang mayang.com/index.php/bappeda/article/view/188.

Samsidar, Samsidar, and Darliana Sormin. 'Program 'Aisyiyah dalam Mewujudkan Keluarga Sakinah Menuju Islam Berkemajuan'. Intiqad: Jurnal Agama Dan Pendidikan Islam 11, no. 1 (1 June 2019): 155-70. https://doi.org/10.30596/ intiqad.v11i1.3142.

Santika, I Gusti Ngurah. 'Optimalisasi Peran Keluarga dalam Menghadapi Persoalan Covid-19: Sebuah Kajian Literatur'. Jurnal Ilmiah Ilmu Sosial 6, no. 2 (18 December 2020): 127-37. https://doi.org/10.23887/jiis.v6i2.28437.

Setiyanto, Danu Aris. 'Konstruksi Pembangunan Hukum Keluarga di Indonesia Melalui Pendekatan Psikologi'. Al-Ahkam 27, no. 1 (9 June 2017): 42. https://doi.org/10.21580/ahkam. 2017.27.1.1183. 
Setyaningsih, Yunika Isma, and Malik Ibrahim. 'Keluarga Berencana dalam Rangka Mewujudkan Keluarga Sakinah di Mungkid, Magelang, Jawa Tengah'. Al-Ahwal: Jurnal Hukum Keluarga Islam 5, no. 2 (26 September 2012): 111-40. http:// ejournal.uin-suka.ac.id/syariah/Ahwal/article/view/1122.

Siregar, Risdawati. 'Urgensi Konseling Keluarga dalam Menciptkan Keluarga Sakinah". Himah II, no. 1 (2015): 77-91. http:// repo.iain-padangsidimpuan.ac.id/262/1/Risdawati Siregar. pdf.

Suarni, Agusdiwana, and Arman Rahim Sawal. 'Peran Akuntansi dalam Rumah Tangga dan Penerapan Pengelolaan Keuangan Rumah Tangga Secara Islami di Masa Pandemi Covid-19'. Assets : Jurnal Ekonomi, Manajemen Dan Akuntansi 10, no. 2 (2020): 110-29. https://doi.org/10.24252/ASSETS.V10I2. 18594.

Syufa'at, Syufa'at. 'Implementasi Maqāșid al-Sharī'ah dalam Hukum Ekonomi Islam'. Al-Ahkam 23, no. 2 (21 October 2013): 143. https://doi.org/10.21580/ahkam.2013.23.2.20.

Zuhriah, Erfaniah. 'Reformasi Gaya Berumah Tangga Melalui Model Keluarga Sakinah dalam Mencegah Perceraian'. ADHKI: Journal of Islamic Family Law 1, no. 2 (2019). 